\title{
PENGARUH PENAMBAHAN KAWAT BENDRAT GALVANIS PADA CAMPURAN BETON TERHADAP KUAT LENTUR BETON
}

\author{
Hamdi $^{1^{*}}$, Dafrimon ${ }^{2}$, Soegeng Harijadi ${ }^{3}$, Revias ${ }^{4}$. \\ ${ }^{1234}$ Jurusan Teknik Sipil, Politeknik Negeri Sriwijaya, Palembang \\ Corresponding Author, Email : hamdimuchtar@yahoo.com
}

\begin{abstract}
ABSTRAK
Kekuatan struktur beton mengidentifikasikan kualitas beton yang digunakan. Semakin tinggi kekuatan struktur beton yang dikehendaki, maka semakin tinggi pula mutu beton yang harus digunakan. Penambahan serat baja berupa kawat bendrat berkait (hooked), diharapkan dapat memperbaiki kualitas beton dari sisi kekuatan lenturnya. Penelitian dilakukan melalui uji sampel yang dilakukan di laboratorium, yaitu dengan menggunakan beton polos mutu K-300 (umur 28 hari), dengan penambahan serat kawat bendrat kadar 0\%, 1\%, 2\%, 3\%, 4\% dan 5\%. Hasil pengujian diperoleh kuat lentur pada beton polos tersebut adalah 1,95 MPa. Pada penambahan 1\%, 2\%, 3\%, 4\% dan 5\% kawat bendrat terhadap campuran, berturut-turut dihasilkan kekuatan lentur sebesar 2,90 MPa, 4,51 MPa, 7,39 MPa, 9,04 Mpa dan 10,64 MPa. Dari trend peningkatan tersebut dapat disimpulkan bahwa penambahan kawat bendrat sebesar 1\% sampai dengan 5\% terhadap campuran beton masih menunjukkan peningkatkan kuatan lentur beton secara linier. Perlu dilakukan penelitian selanjutnya dengan persentase-persentase kawat bendrat yang lebih besar dari 5\% untuk mengetahui jumlah batasan maksimum kawat bendrat terhadapp campuran beton tersebut.
\end{abstract}

Kata Kunci : beton, kawat bendrat, kuat tekan, kuat lentur

\section{PENDAHULUAN}

Beton sebagai bahan konstruksi telah lama dikenal dan paling umum dignakan baik untuk struktur besar dengan bentuk yang sangat rumit, maupun bangunan kecil dengan bentuk yang lebih sederhana. Kelebihan beton dibandingkan material lain adalah harga yang relatif murah karena menggunakan bahan lokal yang mudah didapat, mudah dibentuk sesuai kebutuhan, kekuatan tekan yang tinggi, tahan terhadap api dan perubahan cuaca, serta perawatannya yang relatif mudah dan murah. Disisi lain, beton juga memiliki beberapa kelemahan, antara lain kekuatan tarik dan lenturnya yang rendah dan bersifat getas (brittle) sehingga pemakaiannya menjadi terbatas. Kelenturan yang rendah ini biasanya diatasi dengan penggunaan baja tulangan. Kendala yang masih sering muncul terkait dengan tegangan tarik dan lentur ini adalah walaupun sudah diberi tulangan, terkadang masih saja timbul retak-retak kecil halus arah melintang khususnya pada bagian-bagian yang menerima gaya tarik, yang tentunya berpengaruh terhadap ketahanan struktur bangunan.

Banyak penelitian yang telah dilakukan untuk mengatasi kelemahan beton akibat tegangan tarik dan lentur, salah satunya ialah dengan penambahan serat baja (bendrat). Pemberian serat dengan distribusi secara acak dalam adukan beton dapat menahan perambatan dan pelebaran retak-retak yang terlalu cepat pada beton, baik akibat panas hidrasi maupun akibat pembebanan. (Soroushian dan Bayasi, 1987). 


\section{Tujuan Penelitian}

Penelitian ini bertujuan untuk mencari persentase optimum dari pengaruh penambahan kawat bendrat galvanis dengan fraksi 1\%, 2\%, 3\%, 4\% dan 5\% pada campuran beton normal terhadap kekuatan lentur beton.

\section{Pembatasan Masalah}

Ruang lingkup penelitian yang menjadi batasan penelitian adalah sebagai berikut;

a. Beton yang direncanakan adalah beton normal mutu K-300 (umur 28 hari) dengan komposisi adukan campuran beton berupa semen, agregat halus, agregat kasar dan air berdasarkan formula rancangan campuran (job-mix formula, JMF), dan penambahan serat berupa kawat bendrat.

b. Jenis kawat bendrat yang digunakan adalah kawat galvanis berdiameter $0,8 \mathrm{~mm}$, dipotong sepanjang $10 \pm 0,1 \mathrm{~cm}$ dan kedua ujungnya ditekuk sedemikian rupa sebagai kait (tipe hooked).

c. Pemeriksaan karakteristik hanya dilakukan terhadap agregat kasar dan agregat halus sesuai dengan standar yang berlaku.

\section{TINJAUAN PUSTAKA}

\section{Kajian Terdahulu}

Suhendro (1992), mempelajari pengaruh fiber kawat pada sifat-sifat beton dan beton bertulang. Dalam penelitiannya digunakan tiga jenis kawat lokal yaitu kawat baja, kawat bendrat dan kawat biasa yang berdiameter $\pm 1 \mathrm{~mm}$ dengan panjang $\pm 60 \mathrm{~mm}$. Konsentrasi fiber yang diteliti adalah $0,5 \%$ dan $1 \%$. Diameter kerikil maksimal yang dipakai adalah 20 mm untuk mempermudah penyebaran fiber kawat secara merata kedalam adukan beton. Dari hasil pengujian, disimpulkan bahwa dengan adanya serat pada beton dapat mencegah membesarnya retak-retak rambut, dapat meningkatkan ketahanan terhadap kuat lentur, daktilitas, beban kejut (impact resistance) dan kuat desak.

Widodo (2012), didalam penelitiannya menyimpulkan bahwa penambahan kawat sebagai serat (fiber) mampu meningkatkan kuat tekan beton. Dari hasil pengujian didapatkan kuat tekan beton meningkat $31,65 \%$ pada konsentrasi 7,5\% penambahan fiber.

Siswanto (2011), melakukan penelitian untuk menyelidiki pengaruh penambahan fiber baja lokal pada mortar beton melalui pengujian di laboratorium. Penelitian ini dilakukan pada 87 buah benda uji silinder beton, serta 36 balok beton normal $25 \mathrm{Mpa}$ dengan variasi penambahan persentase berat fraksi fiber baja $0 \%, 2 \%$, dan $4 \%$ terhadap berat mortar beton. Jenis pengujian mencakup kuat tekan, kuat tarik, kuat lentur, dan modulus elastistitas. Berdasarkan hasil uji beton umur 28 hari, penambahan fiber $2 \%$ memiliki kontribusi peningkatan kuat tekan sebesar $6,77 \%$, dan peningkatan modulus elastisitas sebesar 23,09\% terhadap beton polos. Beton fiber $4 \%$ memiliki kontribusi peningkatan kuat tarik sebesar 35,5\% terhadap beton polos. Sedangkan pada beton fiber $2 \%$, terjadi peningkatan kuat tarik lentur sebesar $23,27 \%$ terhadap beton polos. Hasil pengujian tersebut mengindikasikan bahwa semakin besar penambahan fiber baja, tidak memperbesar kontribusi kuat tekan dan kuat tarik lentur beton. Hal ini disebabkan karena menurunnya homogenitas beton akibat penambahan fiber. 
Dafrimon, dkk (2017), melakukan penelitian pengaruh pemakaian kawat bendrat galvanis serat berkait (hooked fiber) terhadap kuat tekan pada campuran beton normal dengan fraksi 1\%, 2\%, 3\%, 4\% dan 5\% di laboratorium. Dari hasil penelitian disimpulkan bahwa kuat tekan beton bertambah pada beton dengan penambahan bendrat $1 \%$, yakni sebesar $5,02 \%$ dari beton normal. Semakin besar tambahan kawat bendrat semakin kecil kuat tekan yang dihasilkan.

Mengacu pada penelitian yang dilakukan tersebut, maka penelitian ini mencoba kembali pemakaian kawat bendrat galvanis untuk peningkatan kuat lentur beton dengan berbagai persentasi berat terhadap berat mortar beton.

\section{Pengertian Beton}

Beton adalah campuran antara semen Portland atau semen hidrolik yang lain, agregat halus, agregat kasar dan air, dengan atau tanpa bahan tambahan yang membentuk massa padat (SNI-03-2847-2002). Menurut Pedoman Beton 1989, Draft Konsesus (SKBI.1.4.53, 1989: 4-5) beton didefinisikan sebagai campuran semen portland atau sembarang semen hidrolik yang lain, agregat halus, agregat kasar dan air dengan atau tanpa menggunakan bahan tambahan.

Seiring dengan penambahan umur, beton akan semakin mengeras dan akan mencapai kekuatan rencana $\left(f^{\prime} c\right)$ pada usia 28 hari. Beton merupakan fungsi dari bahan penyusunnya yang terdiri dari bahan semen hidrolik ( Portland Cement ), agregat kasar, agregat halus, air dan bahan tambah (admixture atau additive). Pada umumnya, beton mengandung rongga udara sekitar $1 \%$ - 2\%, pasta semen (semen dan air) sekitar $25 \%$ $40 \%$, dan untuk agregat (agregat halus dan agregat kasar) sekitar 60\%-75\%.

Disamping kualitas bahan penyusunnya, kualitas pelaksanaan pun menjadi penting dalam pembuatan beton. Kualitas pekerjaan suatu konstruksi sangat dipengaruhi pada pelaksanaan pekerjaan beton berlangsung. Ada empat bagian utama yang mempengaruhi mutu dari kekuatan beton, yaitu : (1). Proporsi bahan-bahan penyusunnya, (2). Metode perancangan, (3). Perawatan dan (4). Keadaan pada saat pengecoran dilaksanakan. (Mulyono, 2004).

\section{Klasifikasi Beton}

Sifat dan karakteristik material penyusun beton akan mempengaruhi kinerja beton yang dibuat, Beton ini harus disesuaikan dengan kelas dan mutu beton (Mulyono, 2004). Menurut SNI - 03-1974-1990 Beton dibagi dalam kelas dan mutu sebagai berikut :

Tabel 1. Kelas dan Mutu Beton

\begin{tabular}{|c|c|c|c|}
\hline $\begin{array}{r}\text { Kelas } \\
\text { Beton }\end{array}$ & Mutu Beton & $\begin{array}{r}\text { Kekuatan Tekan } \\
\left(\mathrm{Kg} / \mathrm{cm}^{2}\right)\end{array}$ & Tujuan Pemakaian Beton \\
\hline I & Bo & $50-80$ & Non-Struktural \\
\hline II & B1 & 100 & Rumah Tinggal \\
& K125 & 125 & Perumahan \\
& K175 & 175 & Perumahan \\
& K225 & 225 & Perumahan dan Bendungan \\
\hline III & $\mathrm{K}>225$ & $>225$ & Jembatan, Bangunan Tinggi, \\
& & & Terowongan Kereta Api \\
\hline
\end{tabular}




\section{Beton Serat}

ACI ( American Concrete Institute ) memberikan definisi pada beton serat, yaitu suatu konstruksi yang tersusun dari bahan semen, agregat halus dan kasar serta sejumlah kecil serat (fibre). Dalam ACI Comittee 544 dikatakan bahwa semua material yang terbuat dari baja/ besi yang berbentuk fisik kecil / pipih dan panjang dapat dimanfaatkan sebagai serat pada beton. Dalam ACI Comittee 544 secara umum fiber baja panjangnya antara 0,5 in $(12,77 \mathrm{~mm})$ sampai 2,5 in $(63,57 \mathrm{~mm})$ dengan diameter antara 0,017 in $(0,45 \mathrm{~mm})$ sampai 0,04 in $(1,0 \mathrm{~mm})$.

Ada beberapa fiber yang sering dipakai dalam campuran beton, salah satunya ialah fiber baja.

Tabel 2. Sifat-Sifat Kawat yang Digunakan Sebagai Bahan Fiber Lokal

\begin{tabular}{|l|c|c|c|}
\hline Jenis Kawat & $\begin{array}{c}\text { Kuat } \\
\text { Tarik } \\
(\mathrm{MPa})\end{array}$ & $\begin{array}{c}\text { Perpanjangan } \\
\text { Pada Saat Putus } \\
(\%)\end{array}$ & $\begin{array}{c}\text { Specific } \\
\text { Gravity }\end{array}$ \\
\hline Kawat Baja & 230,0 & 10,5 & 7,77 \\
\hline Kawat Bendrat & 38,5 & 5,5 & 6,68 \\
\hline Kawat Biasa & 25,0 & 30,0 & 7,70 \\
\hline
\end{tabular}

Kelebihan fiber ini adalah kekuatan dan modulusnya yang tinggi, tetapi fiber ini juga mempunyai kelemahan yaitu sangat korosif. Hal ini akan terlihat bila ada sebagian dari fiber yang tidak terlindung/tertutup beton. Ada beberapa tipe fiber baja yang biasa digunakan :

a. Bentuk fiber baja (steel fiber shapes)
1) Lurus (straight)
6) Bundel (paddled)
2) Berkait (hooked)
7) Kedua ujung ditekuk (enfarged ends)
3) Bergelombang (crimped)
8) Tidak teratur (irregular)
4) Doubel duo form
9) Bergerigi (idented)
5) Ordinary duo form

b. Penampang fiber baja (steel fiber cross section)

1) Lingkaran atau kawat (round atau wire)

2) Persegi atau lembaran (rectangular atau sheet)

3) Tidak teratur atau bentuk dilelehkan (irregular atau melt extract)

c. Fiber dilekatkan bersama dalam satu ikatan (fiber glued together into a bundle). Tipe dari fiber baja dapat ditunjukkan seperti pada Gambar 1.

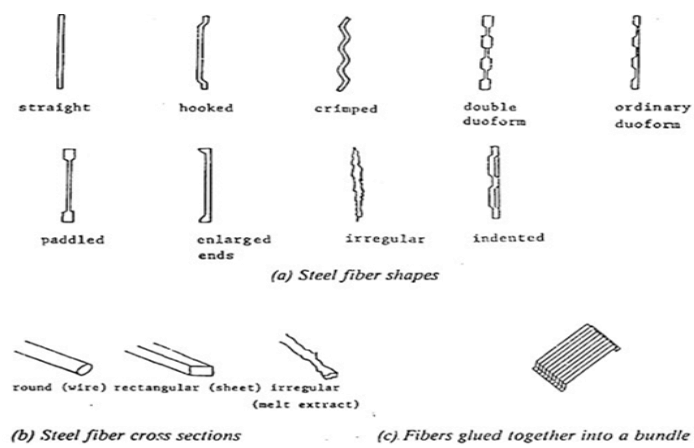

Gambar 1. Bentuk-bentuk geometri serat baja (Soroushian \& Bayasi, 1991) 


\section{Kawat Bendrat Galvanis}

Kawat bendrat berfungsi sebagai pengikat antar baja tulangan agar dapat membentuk struktur seperti yang dikehendaki, kawat bendrat yang digunakan pada penelitian ini ialah jenis kawat bendrat galvanis dimana pada kawat ini adanya proses pelapisan logam anti karat atau non corrosive metal pada besi. Galvanis dapat juga dikenali dari warnanya yang silver atau bronzenamun tidak mengkilat atau doff. Warna itu juga sering disebut dull silver. Untuk tingkat ketebalanya, galvanis punya tingkat ketebalan yang beragam, mulai dari 1 micron sampai 9 micron juga bahkan lebih. Untuk ketebalan 1 micron Salah satu jenis kawat bendrat yaitu kawat galvanis, kawat galvanis dipilih karena merupakan bahan yang mudah diperoleh serta tahan terhadap korosi akibat sifat porous dari beton.

\section{Kuat Lentur Beton}

Kuat lentur balok beton adalah kemampuan balok beton yang diletakkan pada dua perletakan untuk menahan gaya dengan arah tegak lurus sumbu benda uji sampai benda uji patah (SNI 4431: 2011). Uji kuat lentur beton dilakukan pada benda uji berbentuk balok beton bertulang dengan ukuran $100 \mathrm{~mm}$ x $100 \mathrm{~mm}$ x $530 \mathrm{~mm}$.

Menurut Dipohusodo (1993), apabila suatu gelagar balok bentang sederhana menahan beban yang mengakibatkan timbulnya momen lentur, akan terjadi deformasi (regangan) lentur di dalam balok tersebut. Pada kejadian momen lentur positif, regangan tekan terjadi di bagian atas dan regangan tarik di bagian bawah penampang. Reganganregangan tersebut mengakibatkan timbulnya tegangan-tegangan yang harus ditahan oleh balok, tegangan tekan di atas dan tegangan tarik di bagian bawah.

Kuat lentur batas (ultimate flexure strength) beton atau disebut juga modulus keruntuhan (modulus of rupture) adalah beban maksimum yang tercapai selama pembebanan. Menurut ASTM C 78-94, nilai modulus keruntuhan dapat diperoleh dari rumus sebagai berikut:

a. Bila retak terjadi di $1 / 3$ bentang bagian tengah, modulus keruntuhan dapat dilihat dengan persamaan:

$\sigma_{L}=\frac{p_{d}}{b \cdot d^{2}}$

b. Bila retak terjadi di luar 1/3 bentang tengah, modulus keruntuhan dihitung dengan persamaan:

$\sigma_{L}=\frac{P \cdot a}{b \cdot d^{2}}$

dimana:

$\sigma 1=$ Kuat lentur benda uji $(\mathrm{MPa})$

$\mathrm{P}=$ Beban maksimum $(\mathrm{N})$

$\mathrm{L}=$ Bentang balok $(\mathrm{mm})$

$\mathrm{b} \quad=$ lebar rata-rata benda uji $(\mathrm{mm})$

$\mathrm{d} \quad=$ tinggi/tebal rata-rata benda uji $(\mathrm{mm})$

$\mathrm{a} \quad=$ jarak rata-rata antara garis retak dan tumpuan terdekat pada permukaan tarik balok (mm) 
Menurut SNI 2847:2013, untuk beton berbeban normal yang tidak memakai tulangan, nilai modulus keruntuhan dapat diperoleh dari rumus sebagai berikut:

$$
\mathrm{fr}=0,62 \lambda \sqrt{ } \mathrm{f}^{\prime} \mathrm{c}
$$

dimana:

fr $\quad=$ Modulus keruntuhan/kuat lentur batas (MPa)

$\mathrm{f}^{\prime} \mathrm{c}=$ Kuat tekan beton/beton serat $(\mathrm{MPa})$

$\lambda=$ Faktor modifikasi, untuk beton normal $\lambda=1,0$

Kuat lentur dapat diteliti dengan membebani balok pada tengah-tengah bentang atau pada setiap sepertiga bentang dengan beban titik $1 / 2 \mathrm{P}$. Beban ditingkatkan sampai kondisi balok mengalami keruntuhan lentur, dimana retak utama yang terjadi terletak pada sekitar tengah-tengah bentang. Secara sederhana, balok beton digambarkan sebagai struktur simple beam dengan beban terpusat masing-masing 1/2 P. Besarnya momen yang dapat mematahkan benda uji adalah momen akibat beban maksimum dari mesin pembebanan dan berat sendiri dari benda uji. Pada kejadian momen lentur positif, regangan tekan terjadi di bagian atas dan regangan tarik di bagian bawah dari penampang.

Dengan pembebanan pada balok beton dengan tumpuan sederhana dan besarnya beban masing-masing adalah $1 / 2 \mathrm{P}$, maka besarnya momen maksimum yang terjadi pada $1 / 3$ bagian tengah bentang yaitu sebesar:
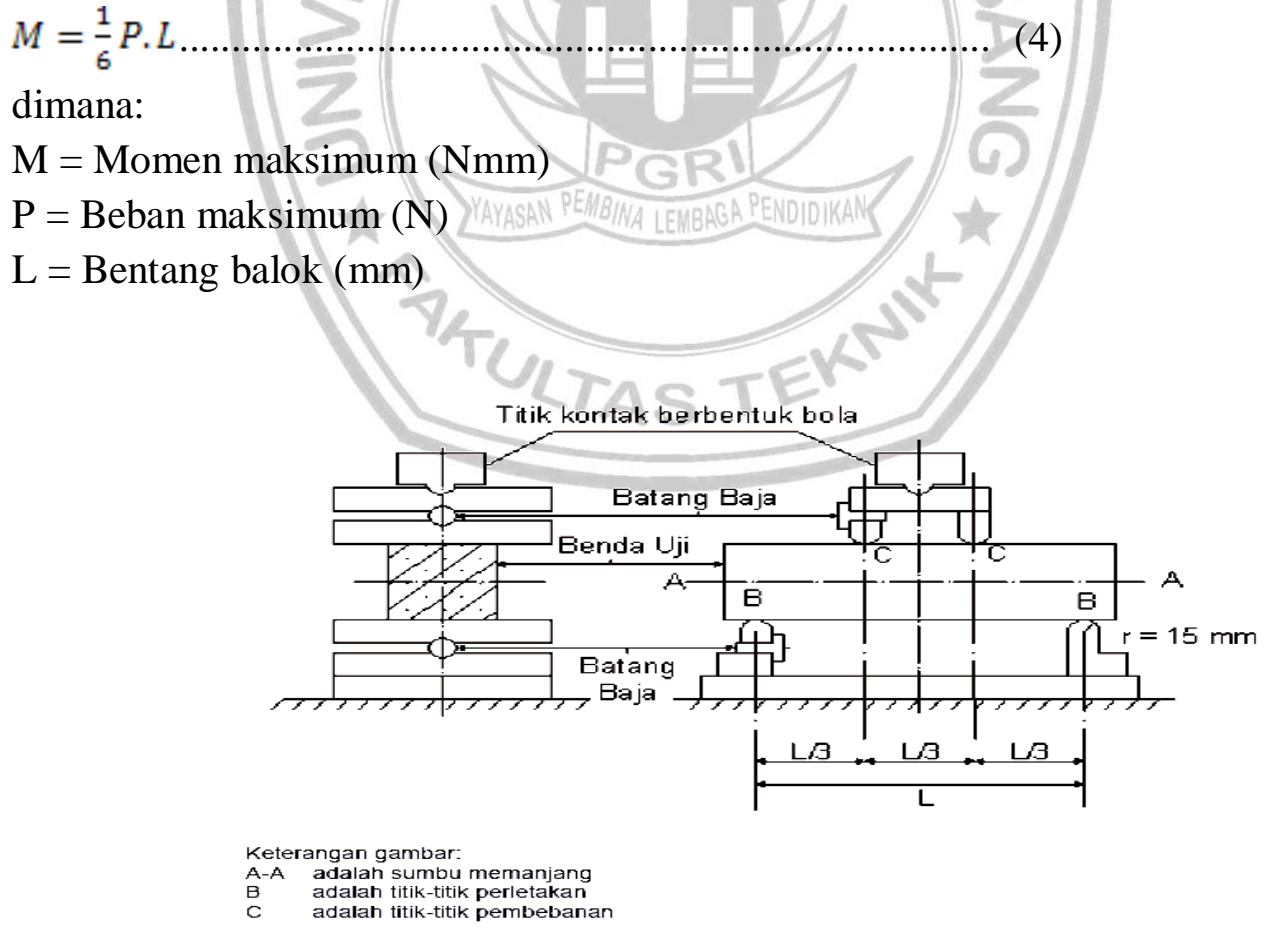

Gambar 2 Benda uji, perletakan dan pembebanan (SNI 4431:2011) 


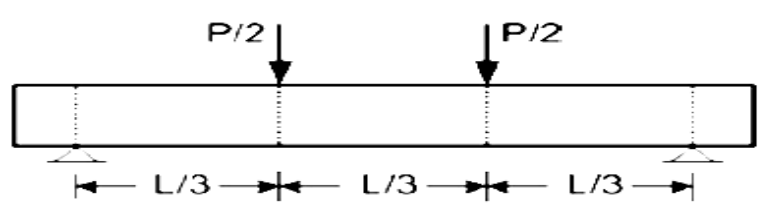

Gambar 3. Balok sederinana yang dibebani gaya $\mathrm{P} / 2$

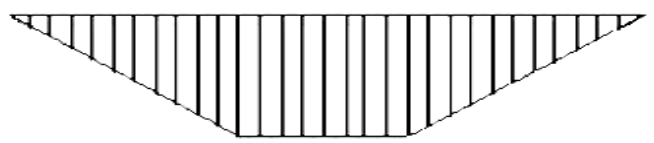

Gambar 4 Diagram momen lentur.

\section{Prosedur perhitungan}

Perhitungan hasil uji dilakukan dengan cara berikut;

a. Untuk pengujian dimana patahnya terjadi di daerah pusat (1/3 jarak perletakan) kuat lentur beton dihitung dengan menggunakan rumus 2.1 .

b. Apabila letak patahan terjadi di luar pusat (di luar $1 / 3$ jarak pembebanan) di bagian tarik beton dengan jarak titik pusat sampai titik patah kurang dari 5\% panjang bentang, maka kuat lentur dihitung dengan rumus 2.2.

c. Jika letak patahan berada di luar pusat (diluar 1/3 jarak perletakan) dibagian tarik beton dengan jarak lebih dari 5\% dari bentang maka hasil pengujian tidak digunakan.

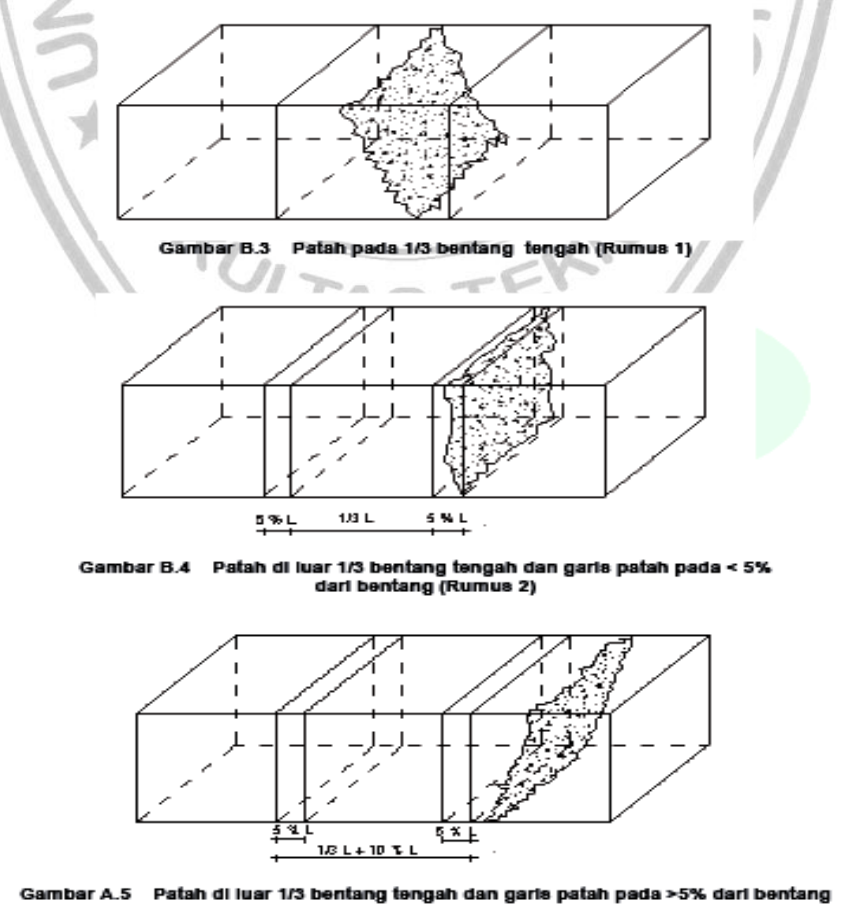

Gambar 5 Posisi patahan pada balok beton akibat pembenanan (SNI 4431:200) 


\section{Umur Beton}

Kekuatan tekan beton akan bertambah dengan naiknya umur beton. Kekuatan beton akan naiknya secara cepat (linier) sampai umur 28 hari, tetapi setelah itu kenaikannya akan kecil. Kekuatan tekan beton pada kasus-kasus tertentu terus akan bertambah sampai beberapa tahun dimuka. Biasanya kekuatan tekan rencana beton dihitung pada umur 28 hari.

Untuk struktur yang menghendaki kekuatan awal tinggi, maka campuran dikombinasikan dengan semen khusus atau ditambah dengan bahan tambah kimia dengan tetap menggunakan jenis semen tipe 1. Laju kenaikan umur beton sangat tergantung dari penggunaan bahan penyusunnya yang paling utama adalah penggunaan bahan semen karena semen cenderung secara langsung memperbaiki kinerja tekannya. (Mulyono, 2004)

\section{METODE PENELITIAN}

\section{Lokasi Penelitian}

Lokasi penelitian yang diambil terbagi atas dua, yaitu :

a. Lokasi pengambilan material

Lokasi pengambilan material agregat berada di Tanjung Raja kabupaten Ogan Ilir, sedangkan semen (PC), kawat bendrat dari toko bahan bangunan di Kota Palembang.

b. Lokasi penelitian

Pelaksanaan penelitian dilakukan di Laboratorium Pengujian Bahan Jurusan Teknik Sipil Politeknik Negeri Sriwijaya Palembang.

\section{Jenis Penelitian}

Penelitian ini terdiri dari dua variabel, yaitu:

a. Variabel bebas disini adalah kawat bendrat yang di kombinasikan dengan beton. Jumlah yang digunakan pada setiap benda uji dibedakan berdasarkan variasi persentase bendrat $0 \%, 1 \%, 2 \%, 3 \%, 4 \%, 5 \%$ dengan masing-masing 3 benda uji berupa balok.

b. Variabel terikat; Variabel terikat disini adalah besarnya pengaruh campuran dari kombinasi kawat bendrat terhadap kuat tekan yang dihasilkan. Untuk 72 buah benda uji telah direncanakan dengan mix design berdasarkan SNI 03-2843-2000. Pengujian kuat lentur beton dilakukan di umur 28 hari masa perawatan benda uji. Jumlah sampel yang diambil terdiri dari 3 buah benda uji untuk setiap persentase kombinasi kawat bendrat $(0 \%, 1 \%, 2 \%, 3 \%, 4 \%, 5 \%)$ maka total benda uji balok adalah 18 buah. 


\section{Tahapan Penelitian}

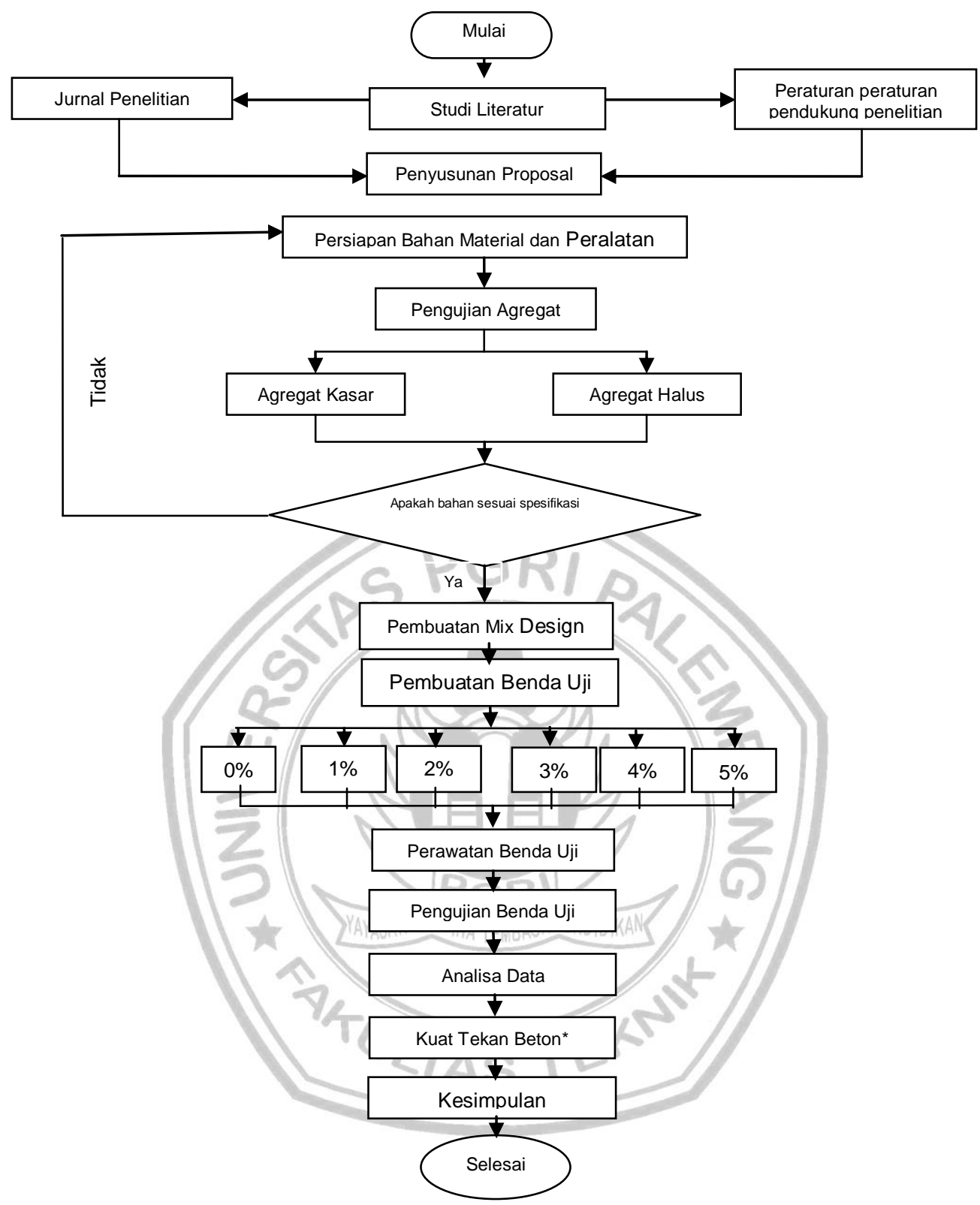

Gambar 6. Diagram ALir Proses Penelitian

\section{HASIL DAN ANALISA DATA}

\section{Analisa Bahan}

Untuk mengetahui sifat - sifat meterial yang digunakan dalam perancangan campuran beton, perlu dilakukan pemeriksaan khusus terhadap material yang akan digunakan. Hal ini dimaksudkan agar didapatkan informasi yang diperlukan dalam perhitungan proporsional rancangan campuran beton (job-mix formula, $J M F$ ). 


\section{Pemeriksaan Agregat Halus}

Tabel 3. Rekapitulasi Pemeriksaan Agregat Halus

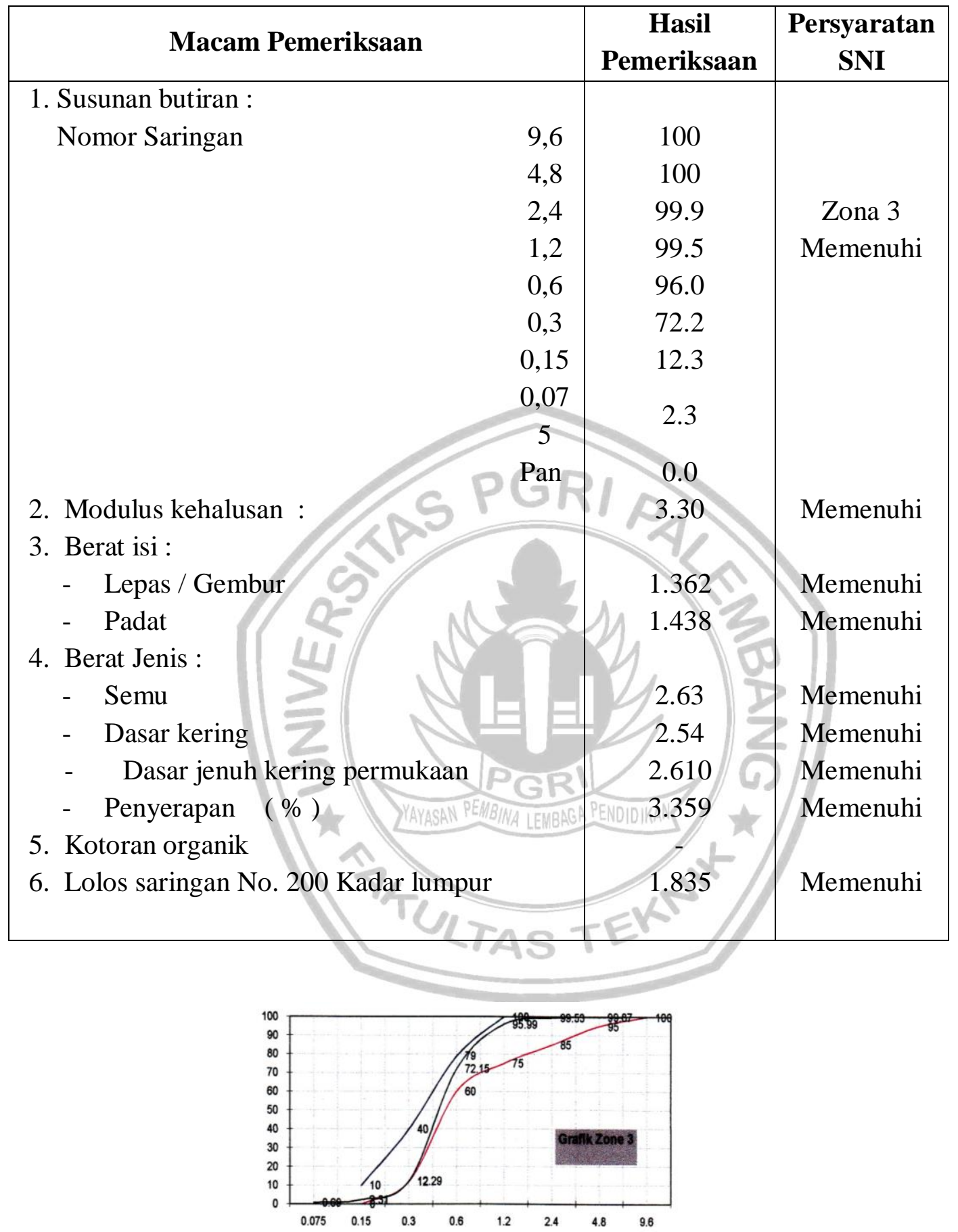

Gambar 7. Grafik Analisa Saringan dari Agregat yang digunakan untuk pembuatanbenda uji kubus beton. 


\section{Pemeriksaan Agregat Kasar}

Tabel 4. Rekapitulasi Pemeriksaan Agregat Kasar

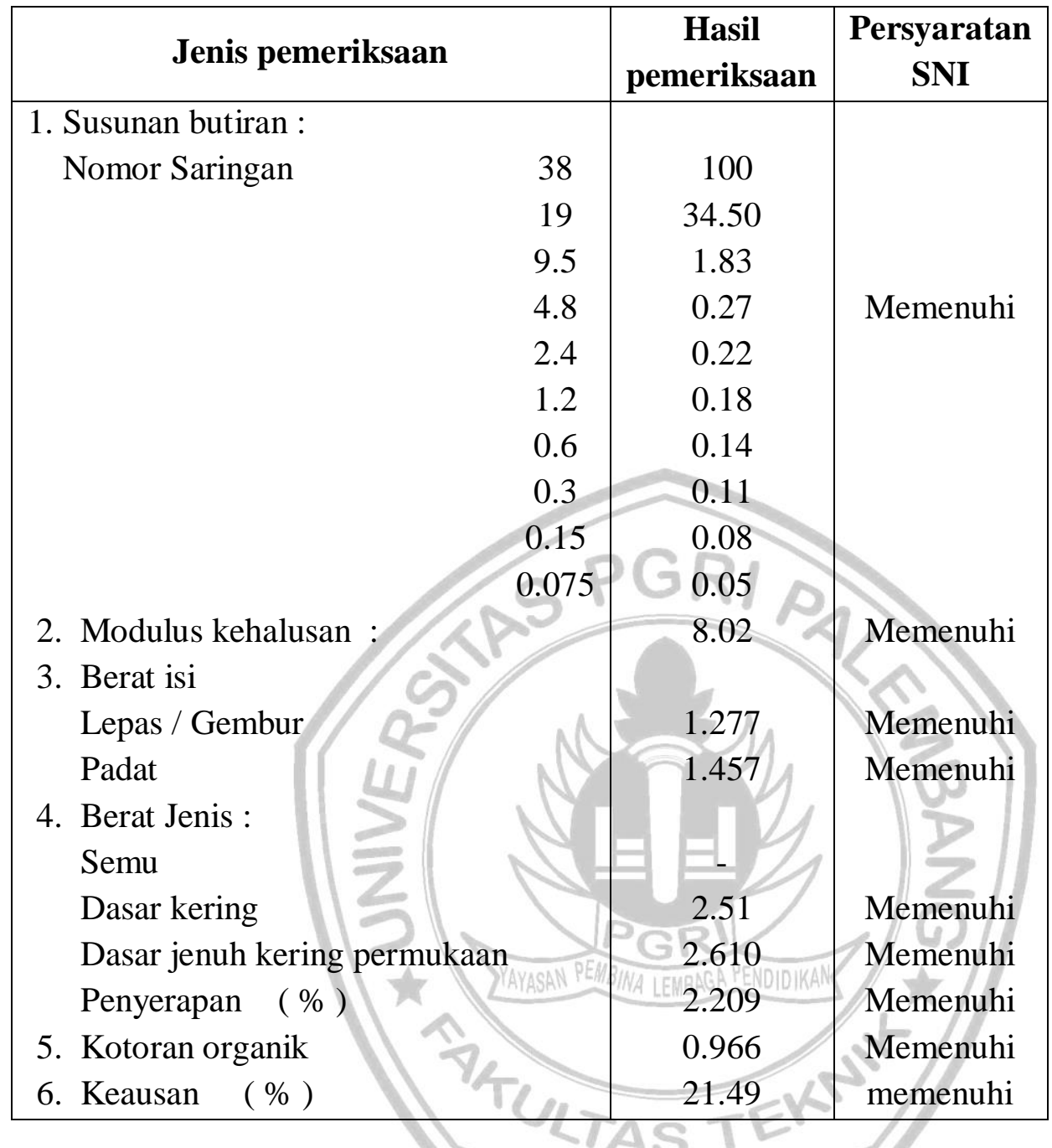

\section{Pengujian Kuat Lentur Beton.}

Pengujian kuat lentur beton dilakukan berdasarkan pedoman yang tertuang dalam SNI 4431:2011 tentang cara uji kuat lentur beton polos dengan dua titik pembebanan. Hasil penekanan dibawah mesin tekan beton terhadap balok beton ukuran $10 \times 10 \times 50 \mathrm{~cm}$, dengan penambahan $0 \%, 1 \%, 2 \%, 3 \%, 4 \%$ dan 5\% kawat bendraat setelah 28 hari perawatan dapat dilihat pada Tabel 5 berikut ini. 
Tabel 5. Hasil pengujian kuat lentur beton dengan penambahan $0 \%, 1 \%, 2 \%, 3 \%, 4 \%$ dan $5 \%$ kawat bendrat.

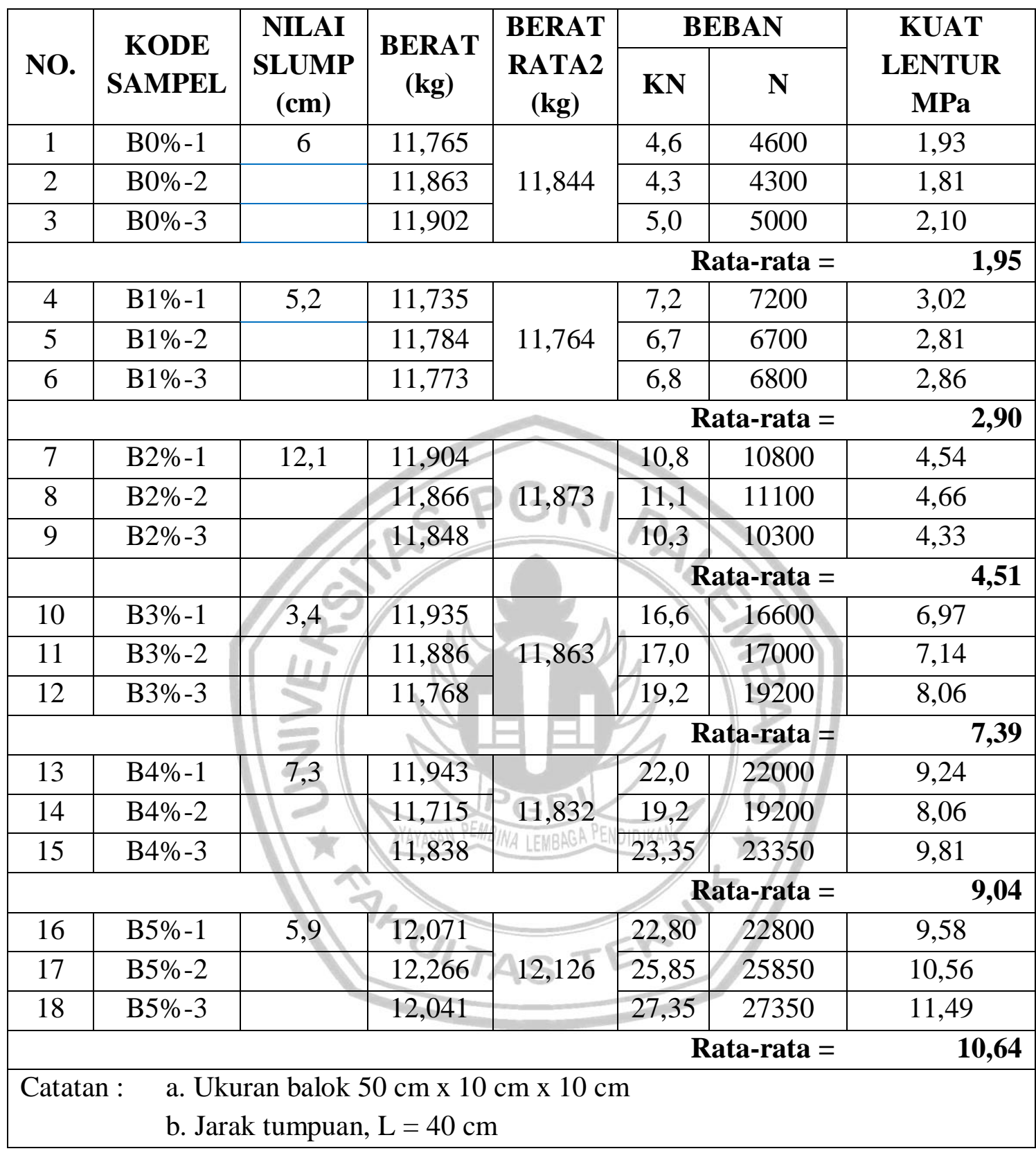

Kuat lentur yang diperoleh dari hasil pengujian sebgaimana pada Tabel 4.18 diatas (berkisar antara 1,95 MPa sampai 10,64 MPa. Pada campuran beton polos (penambahan $0 \%$ bendrat) diperoleh kekuatan lentur rata-rata sebesar 1,95 MPa. Pada campuran beton dengan penambahan $1 \%$ bendrat, diperoleh kekuatan lentur rata-rata sebesar 2,90 MPa. Pada campuran beton dengan penambahan $2 \%$ bendrat, diperoleh kekuatan lentur rata-rata sebesar 4,51 MPa. Pada campuran beton dengan penambahan 3\% bendrat, diperoleh kekuatan lentur rata-rata sebesar 7,39 $\mathrm{MPa}$, sedangkan pada campuran beton dengan penambahan $4 \%$ bendrat, diperoleh kekuatan lentur rata-rata sebesar 9,04 MPa dan pada penambahan $5 \%$ bendrat diperoleh kekuatan lentur sebesar 10,64 MPa. Hasil ini dapat ditampilkan melalui grafik pada Gambar 8. 
Dari grafik tersebut dapat disimpulkan bahwa kuat lentur beton polos dengan umur 28 hari pada penelitian ini adalah 1,95 MPa. Dengan penambahan kawat bendrat terhadap campuran beton berturut-turut sebesar 1\%,2\%,3\%, 4\% dan 5\% diperoleh peningkatan terhadap kekuatan lentur beton.

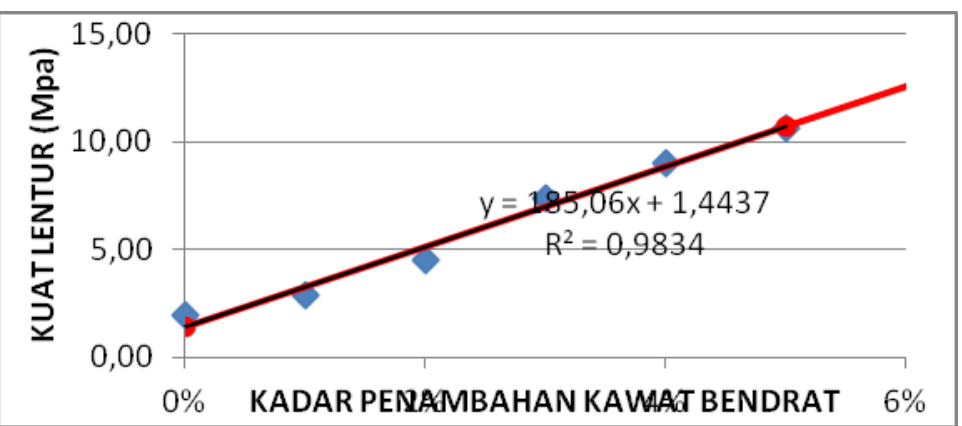

Gambar 8 Grafik hubungan kuat lentur dengan penambahan kawat bendrat.

Dari grafik tersebut dapat dilihat bahwa peningkatan kekuatan lentur secara linier bertambah seiring dengan penambahan kadar kawat bendrat, sehingga membentuk sebuah trend garis regresi sederhana dengan persamaan $y=185,06 x+1,4437$ dan $R^{2}=0,9834$. Dari hasil percobaan, besarnya kadar kawat bendrat yang digunakan dalam campuran beton mampu meningkatkan mutu beton dalam menahan beban lentur.

\section{KESIMPULAN}

Berdasarkan penelitian yang telah dilaksanakan di laboratorium pengujian material Politeknik Negeri Sriwijaya dapat ditarik kesimpulan sebagai berikut :

1) Kuat tekan rencana untuk beton polos (umur 28 hari) dengan K300, secara teoritis idealnya adalah minimal sebesar $300 \mathrm{~kg} / \mathrm{cm} 2$ (24,42 MPa). Dari hasil pengujian, kuat tekan beton normal adalah $302,13 \mathrm{~kg} / \mathrm{cm} 2(24,59 \mathrm{MPa})$. Hal ini berarti mutu bahan dan rancangan campuran beton (job-mixed formula, JMF) telah sesuai persyaratan yang ditentukan..

2) Kuat lentur pada beton polos (umur 28 hari) tersebut adalah 1,95 MPa. Pada penambahan $1 \%, 2 \%, 3 \%, 4 \%$ dan $5 \%$ kawat bendrat terhadap campuran, menghasilkan kekuatan lentur berturut-turut sebesar 2,90 $\mathrm{MPa}, 4,51 \mathrm{MPa}, 7,39 \mathrm{MPa}$, 9,04 MPa dan 10,64 MPa.

3) Dari trend peningkatan tersebut dapat disimpulkan bahwa dengan penambahan kawat bendrat terhadap campuran beton polos dapat meningkatkan kekuatan lentur beton yang akhirnya dapat meningkatkan mutu beton.

\section{SARAN}

Perlu dilakukan penelitian lebih lanjut untuk kadar-kadar (persentase campuran) kawat bendrat yang lebih besar dari 5\% untuk mengetahui batas persentase campuran kawat bendrat yang masih bisa digunakan dalam campuran beton polos. 


\section{DAFTAR PUSTAKA}

Dafimon, H. Soegeng, Hamdi (2017) Pengaruh Pemakaian Kawat Bendrat Galvanis Sebagai Bahan Tambah pada Campuran Beton Terhadap Kekuatan Beton, Palembang.

Departemen Pekerjaan Umum (1990) Metode Pengujian Kuat Tekan Beton, SK SNI 031974-1990, Bandung

Departemen Pekerjaan Umum (1990) Metode Pengujian Berat Jenis dan Penyerapan Agregat Kasar, SNI M-09 $1989-F$, Bandung

Departemen Pekerjaan Umum (1990) Metode Pengujian Kuat Tekan Beton, SK SNI 031974-1990, Bandung

Departemen Pekerjaan Umum (2011) Metode Uji Tekan Slinder yang Dicetak, SK SNI 1974-2011, Bandung

Departemen Pekerjaan Umum (2011) Cara Uji Kuat Lentur Beton Normal dengan Dua Titik Pembebanan, SNI 4431:2011, Bandung

Departemen Pekerjaan Umum (1989) Spesifikasi Bahan Bangunan Bagian A, SK SNI S04 - 1989-F, Bandung

Mulyono, Tri. 2004. Teknologi Beton. Edisi 2. Penerbit Andi. Yogyakarta.

Murdock, L.J Brook, B.M Stephanus H. 1999. Bahan dan Praktek Beton. Erlangga. Jakarta.

Nawy, E.G, 1990. Beton Bertulang Suatu Pendekatan Dasar. Erlangga. Jakarta

Siswanto, A. (2011) Pengujian Fiber Baja pada Kapasitas Tarik dan Lentur Beton, Industrial Research Workshop and National Seminar 2011, Bandung.

SNI. 03-2847-2002. Tata Cara Perhitungan Struktur Beton. Beta Version. Bandung

Soroushian, P., Bayasi, Z. 1991. Fiber Type Effects on the Performance of Steel Fiber Reinforced Concrete. Michigan State University. Michigan, USA.

Suhendro. 2012. Pengaruh Fiber Kawat Lokal Pada Sifat-sifat Beton. Teknikinfra.blogspot.co.id, diakses tanggal 8 Mei 2017.

Widodo, Anis. Beton Dengan Serat Penyaring 4cm Berat Semen 350 kg/m3 dan FAS 0,5. http://journal.unnes.ac.id, diakses tanggal 08 Mei 201 